\title{
PIĘKNO PŁASZCZEM DOBRA. OD PLOTYNA DO STRÓŻEWSKIEGO I TISCHNERA
}

Na początku jest dobro - przynajmniej według Platona. Pisze on w Timajosie: "Jeśli ten świat jest piękny, a jego konstruktor jest dobry, jasno stąd wynika, że patrzył na model wieczny. [...] Świat bowiem jest rzeczą najpiękniejszą spośród zrodzonych, a jego budowniczy jest najdoskonalszą z przyczyn"1. Powstaje pytanie, dlaczego demiurg powołał świat do istnienia. „Odpowiadamy: był dobry. A kto jest dobry, nie odczuwa nigdy żadnej zazdrości wobec nikogo" 2 .

Model wieczny, na który patrzył budowniczy, to świat idei: „na szczycie świata myśli stoi idea dobra - pisze Platon - ona jest dla wszystkiego przyczyną wszystkiego, co słuszne i piękne, że w świecie widzialnym pochodzi od niej światło i jego pan, a w świecie myśli ona panuje i rodzi prawdę i rozum"3. Świat stworzony przez Dobro, przez Dobrego, jest dobry i piękny.

Piękno i dobro zostają utożsamione ze sobą, bo: "co dobre, to i piękne" 4 , jedno i drugie jest najwyższym celem pragnień, dążeń i miłości, dopiero wtedy „życie jest coś warte [...], gdy człowiek piękno samo w sobie ogląda" 5 .

\footnotetext{
${ }^{1}$ Platon, Timajos 29 a, tłum. P. Siwek, Warszawa 1986, s. 35.

2 Ibidem, 29 d, s. 36.

3 Platon, Państwo, ks. VII, 517 b, c, tłum. W. Witwicki, Warszawa 1990, s. 364.

4 Platon, Uczta 201 b c, tłum. W. Witwicki, Warszawa 1982, s. 98.

${ }^{5}$ Ibidem, 211 d, s. 116.
} 
Bliskość dobra i piękna przejawia się więc raz jako ich utożsamienie, to znów w ten sposób, że piękno wypływa z dobra, świadczy o nim i do niego prowadzi. Wątek ten jest bardzo ważny w myśli Plotyna, według którego Jednia (określana też jako Dobro) emanuje z siebie kolejne hipostazy: umysł (czyli ducha), duszę świata, dusze ludzkie i wreszcie jako ostatni, na granicy nicości, pojawia się świat rzeczy: cielesny i zmysłowy. Piękno łączy się przede wszystkim ze sferą umysłu, zapatrzonego w swoje źródło (czyli Dobro), a równocześnie dalej udzielającego siebie, emanującego duszę.

Zadaniem człowieka jest odwrócenie się od świata zmysłowego i kierowanie w stronę świata myśli, siedziby niewidzialnego piękna: „Trzeba więc znowu wspinać się do dobra, którego pragnie każda dusza. Kto je ujrzał, ten wie, o czym mówię, wie, jak jest piękne”"6. Trzeba kierować się do tego, „ku czemu wszystko patrzy i istnieje, i żyje, i myśli [...], albowiem Ono jest przyczyną życia i umysłu, i istnienia"7. Ten cel wszystkich dążeń i przyczynę wszystkiego, wyższą niż umysł, "nazywamy naturą Dobra, dzierżącą przed sobą jakby puklerz piękna"8.

Dobro, udzielając istnienia, ukazuje się jako piękno, jako blask tego, co istnieje ${ }^{9}$. Świat widzialny jest piękny tylko dzięki temu, że odzwierciedla w sobie piękno niewidzialne, duchowe.

Neoplatońska koncepcja piękna, dzięki pośrednictwu Dionizego Areopagity i Eriugeny, przechodzi do filozofii średniowiecznej. Sformułowana przez Dionizego definicja: Euarmostia kai aglaja (łacińskie consonantia et claritas) $)^{10}$, wprowadza rozumienie piękna jako blasku, światła, jasności. Jaśniejące blaskiem piękna widzialne formy "są wyobrażeniami niewidzialnego piękna, przez które boska opatrzność umysły ludzkie zwraca z powrotem ku czystemu i niewidzialnemu pięknu samej prawdy"11. W tych słowach Eriugeny zawiera się istota neoplatońskiego dziedzictwa: piękno widzialne odsyła do niewidzialnego, duchowego piękna. Piękno widzialne świadczy o pięknie wyższym, objawia je i doprowadza ludzi do niego.

${ }_{6}^{6}$ Plotyn, Enneada I, VI, wyd. II, tłum. A. Krokiewicz, Warszawa 2000, s. 137.

7 Ibidem.

8 Ibidem, s. 140.

9 "Gdzież bowiem może istnieć piękno pozbawione istnienia i gdzie może istnieć substancja pozbawiona istotnego piękna? Zaprawdę, w razie niedostatku piękna niedostaje także substancji. Dlatego i istnienie jest pożądane, ponieważ jest tym samym, co piękno, i piękno zachwyca, ponieważ jest istnieniem. Skoro zaś ich natura jest jedna, to po co dociekać, które którego z nich jest przyczyną?" (Plotyn, Ennada V, VIII, op. cit.). Jest tu już zalążek koncepcji transcendentaliów.

10 Por. W. Stróżewski, Z zagadnień piękna i dzieła sztuki, [w:] Historia filozofii średniowiecznej, red. J. Legowicz, Warszawa 1979, s. 483. Zob. też: idem, Claritas: Uwarunkowania historyczne i treść estetyczna pojęcia, „Estetyka” 1961, r. II, s. 125-146.

${ }^{11}$ Jan Szkot Eriugena, [cyt. za:] W. Stróżewski, Z zagadnień piękna..., op. cit., s. 484. 
Święty Tomasz z Akwinu dołącza do dwóch określeń Areopagity jeszcze trzecie: doskonałość, pełnię. „Doskonałość, perfectio, jest warunkiem dobra” - pisze Władysław Stróżewski, komentując myśl Tomasza. „Dobro to doskonałość jako przedmiot pożądania”. Natomiast: „Piękno to także osiągnięte dobro, ujmowane jednak [...] jako przedmiot kontemplacji"12. Znów dobro i piękno się utożsamiają, "różnią się tylko pojęciowo"13. Powstaje klasyczna teoria transcendentaliów, według której pojęcia transcendentalne są równozakresowe i zamienne, to znaczy byt, rzecz, jedność, prawda, dobro i piękno się utożsamiają.

W myśli współczesnej pojawia się przekonanie o wartościowości bytu jako obiektywnej, a nie jedynie subiektywnej danej. Tak sądzą fenomenologowie, np. Max Scheler, który utrzymywał, że byt ujmowany jako neutralny to wytwór abstrakcji robionej dla potrzeb nauki.

Także Stróżewski jest przekonany, że w pierwotnym ludzkim doświadczeniu bycie, istnienie nie jest czymś obojętnym, lecz jawi się jako nacechowane pewnymi znaczeniami, wartościami, jakościami, że budzi pewne emocje, że pytanie o zasady bytu jest od początku europejskiego myślenia jednocześnie pytaniem o wartości. Pytania te są "zakorzenione w najbardziej ludzkiej potrzebie poszukiwania sensu rzeczywistości [...]. Pytania: dlaczego tak jest? Dlaczego tak się dzieje? - znaczą także: czy tak jest dobrze czy źle? A są one nie tylko równie ważkie, jak pytania o zasadę, arche [...]. Należą do tego samego, co one, porządku. Stanowią, wraz z nimi, jeden problem"14. Odnawiając Tomaszową koncepcję transcendentaliów, wychodzi więc Stróżewski od doświadczenia istnienia i wynikających z niego najbardziej podstawowych pytań.

„W samym bycie więc - pisze dalej Stróżewski - musi znajdować się coś, co zmusza nas do jego wielorakiego doświadczenia i co pozwala w konsekwencji ująć go jako jedność, prawdę czy dobro"15. Czyli „dla Tomasza podstawą wszystkich transcendentalnych doskonałości bytu jest akt istnienia"16. Istnienie samo jest doskonałością, nic nie byłoby prawdziwe, dobre czy piękne, gdyby nie istniało.

Ostatecznie transcendentalia „jawią się jako niezbędny warunek urzeczywistniania się wartości"17. W ten sposób Stróżewski przyjmuje istnienie co najmniej dwóch poziomów: transcendentaliów i wartości.

\footnotetext{
12 W. Stróżewski, Z zagadnień piękna..., op. cit., s.490.

13 Ibidem

14 W. Stróżewski, Transcendentalia i wartości, [w:] idem, Istnienie i wartość, Kraków 1981, s. 12.

${ }^{15}$ Ibidem, s. 17; por. też: ibidem, s. 16.

16 Ibidem, s. 42.

17 Ibidem, s. 95.
} 
Podobnie Józef Tischner, na przykład w Myśleniu według wartości, stwierdza, że świat, w którym żyjemy, przeniknięty jest wartościami - pozytywnymi lub negatywnymi; jest światem spraw i rzeczy, które nas poruszają i angażują. Jednak nie zgadza się z ideą tożsamości dobra, piękna i prawdy. Dobro, prawda i piękno, nazywane transcendentaliami ${ }^{18}$, pokrywają się może na wyżynach abstrakcji, w idealnym świecie, ale w świecie doczesnym są $\mathrm{w}$ sporze ${ }^{19}$. Byt nie jest dobry przez to tylko, że istnieje, ale domaga się usprawiedliwienia.

Istnienie potrzebuje więc usprawiedliwienia dzięki wartościom, bez nich pozbawione jest sensu, wręcz absurdalne, i może być doświadczane jako do gruntu złe ${ }^{20}$. Istnienie może zostać usprawiedliwione albo nie, czyli - mówiąc językiem religijnym - może zostać zbawione lub potępione. Na tym polega dramatyczność życia ludzkiego i relacji z drugim człowiekiem.

Piękno obiecuje usprawiedliwienie istnienia, ofiaruje ocalenie, nadanie sensu cierpieniu, udział „W samym źródle bycia" 21. „Wydarzenie piękna” jest jak „wydarzenie sensu”: „dzięki wydarzeniu piękna człowiek dotyka rdzeniem swej osoby czegoś, co ma moc usprawiedliwiania lub odmowy usprawiedliwienia jego obecności na scenie świata"22.

W spotkaniu z drugim człowiekiem piękno jest światłem, które wydobywa to, co najcenniejsze $\mathrm{w}$ drugim, także jego czy jej wewnętrzne, niewidzialne bogactwo.

Podobnie jak łaska, piękno jest niespodzianką, niezasłużonym darem, obietnicą czegoś innego i czegoś więcej. Dzięki spotkaniu z drugim, z jego pięknem, pojawia się „perspektywa [...] uczestnictwa w samym źródle sensu bycia" 23. To nie muszą być fałszywe obietnice, ale mogą. Poryw zachwytu, wzlot dzięki pięknu nie jest tu, jak u Platona, prostą drogą do absolutu, lecz nieraz kieruje na manowce.

Piękno drugiego może oczarować, przyprawić o szaleństwo, nawet zniewolić. Budzi tęsknotę i pragnienie posiadania, które zderza się z poczuciem niemocy. Piękno pociąga i wymyka się, jawi się nawet czasem jako okrutne i nieludzkie. Postacie dramatu toczącego się $\mathrm{w}$ żywiole piękna (konkretnych przykładów Kierkegaardowi, a potem Tischnerowi dostarczają bohaterowie oper Mozarta oraz Johannes i Kordelia z Dziennika uwodzi-

18 Por. J. Tischner, Spór o istnienie człowieka, Kraków 1998, s. 200; oraz: idem, Filozofia człowieka dla duszpasterzy i artystów, Kraków 1991, s. 21.

${ }_{19}^{19}$ J. Tischner, Filozofia dramatu, Paris 1990, s. 46.

20 Por. J. Tischner, Spór o istnienie człowieka, op. cit., rozdz. „Wędrówka wokół widoku zła”.

${ }^{21} \mathrm{~J}$. Tischner, Filozofia dramatu, op. cit., s. 98.

22 Ibidem, s. 93

${ }^{23}$ Ibidem, s. 98. 
ciela) są uwikłane w skomplikowane emocje i relacje, we wzajemne próby uprzedmiotowienia i wzięcia drugiego w posiadanie. Są, jak mówi Tischner, "estetycznie w sobie zaplątani”" 24 , pogrążają się w czymś w rodzaju „piekła”25.

Dlaczego się tak dzieje? Tischner za Kierkegaardem dostrzega wieloznaczność piękna: „światła, które daje życie i odbiera życie”, płomienia, „który grzeje, ale również pali”26. Bezinteresowność piękna może być rozumiana jako obojętność $\mathrm{w}$ stosunku do istnienia i nieistnienia, jak to jest u Romana Ingardena i Immanuela Kanta. Jednak pozostaje ciągle przekonanie, że to, co piękne, powinno istnieć. Korzysta z tego sztuka, tworząc świat pięknej ułudy ${ }^{27}$. Z kolei poczucie niemocy wobec piękna i związane $\mathrm{z}$ tym cierpienie wywołują pragnienie kontrolowania piękna, wzięcia w posiadanie, uprzedmiotowienia.

W rezultacie "osoba - podmiot dramatu - szuka dla siebie ocalenia w pięknie, które tworzy lub w którym ma udział" 28 . Sądzi ona, że nie ma innego wyjścia, jak tylko „uczynić ze swego cierpienia i cierpienia w ogóle wspaniałe arcydzieło" 29 i zmusić innych do podziwu. Jeśli człowiek nie potrafi ocalić się dzięki prawdzie ani dzięki dobru, pozostaje mu piękno. Może ono istnieć samodzielnie i $\mathrm{w}$ tym sensie jest absolutne. Cierpienie (a nawet zło) staje się tworzywem, które zostaje przetworzone w piękną tragedię, tragedię estetyczną, która budzi podziw i zachwyt. Człowiek gra, kreuje siebie, swoje życie, swoje relacje $\mathrm{z}$ innymi, konstruuje drugiego człowieka jak dzieło sztuki. Piękno wszystko usprawiedliwia. W ten sposób ma dokonać się zbawienie, ocalenie przez sztukę i piękno: „sztuka staje się religią człowieka" 30 .

Rozwiązanie takie dostrzega Tischner u starożytnych Greków, u Nietzschego, u dziewiętnastowiecznych romantyków (może lepiej powiedzieć: dandysów i dekadentów).

Obietnica ocalenia przez sztukę i piękno jednak zawodzi, „,oczarowanie nie stwarza wierności" 31 - pisze Tischner. To znaczy, że relacja, która tu powstaje, jest powierzchowna, nie sięga tego, co w osobie najgłębsze. Zbawienie przez sztukę nie ratuje przed rozpaczą.

\footnotetext{
${ }^{24}$ Ibidem, s. 106.

25 Ibidem, s. 108.

26 Ibidem, s. 101.

27 Por. ibidem, s. 97-98.

${ }^{28}$ J. Tischner, Filozofia człowieka dla duszpasterzy i artystów, op. cit., s. 53.

${ }^{29}$ Ibidem.

${ }^{30}$ Ibidem.

${ }^{31}$ J. Tischner, Filozofia dramatu, op. cit., s. 103.
} 
Piękno zatem to żywioł, w którym łatwo pobłądzić. Żywioł rozumie tu Tischner jako „umiejscowienie życia”, coś, co jest całkowitym przeciwieństwem czegoś gotowego, określonego, nieruchomego, a co kojarzy się z samym życiem, jego energią i dynamiką. Żywioły nas otaczają, jesteśmy w nich zanurzeni, działamy raczej pod ich wpływem, niż sami zdolni jesteśmy je kształtować. Podczas wędrówki, jaką jest życie, można zabłądzić zgodnie z tytułami rozdziałów w książce Filozofia dramatu - w żywiole piękna, w żywiole prawdy albo $\mathrm{w}$ żywiole dobra. Tyle tylko, że zbłądzenie w żywiole prawdy polega na wyborze kłamstwa, w żywiole dobra na wyborze zła (choć ono często ukazuje się pod postacią dobra), a w przypadku piękna na manowce sprowadzić potrafi ono samo. Piękno okazuje się zwodnicze i wieloznaczne.

Także relacje między transcendentaliami (nazywanymi też ideałami wartości, ideami aksjologicznymi, żywiołami) są dramatyczne, nie jedność między nimi panuje, lecz spór. Jedność jest może celem czy postulatem, ale to, z czym mamy faktycznie do czynienia, to spór o pierwszeństwo, a może nawet o wyłączność.

Spór się zaostrza, kiedy Tischner odróżnia dobro i wartości. Dobro jest źródłem światła, a wartości tym, co oświetlane; są one przedmiotowe: piękno dane jest jako przedmiot podziwu, wartości moralne dane są do realizacji32. Uczestnictwu w dobru przeciwstawia się - a nawet zagraża mu uprzedmiotowienie dobra, które „sprowadzone do porządku wartości staje się wartością estetyczną" 33 . Estetyzacja polega na utożsamieniu dobra i piękna: „absolut dobra staje się absolutem piękna”34. Tischner niewątpliwie ma na myśli redukcję dobra, groźbę jego uprzedmiotowienia, ale brzmi to też tak, jakby ostrzegał przed nieuprawnionym awansowaniem piękna. Za tym kryje się założenie o prymacie dobra w stosunku do piękna.

Dwie są możliwości, konkluduje Tischner ${ }^{35}$ : albo absolutyzacja piękna w sytuacji, kiedy piękno usprawiedliwia wszystko (fałsz, zło, jeśli tylko jest piękne, zostaje usprawiedliwione), albo przejście z poziomu estetycznego na poziom dobra, w terminach Kierkegaarda - na poziom etyczny i religijny. Czy wobec tego piękno trzeba odrzucić? Uznać ciało za "żertwę ofiarną", uwodzenie zastąpić wiernością, przypomnieć, że zbawienie w chrześcijaństwie dokonuje się nie poprzez piękno, lecz poprzez śmierć Chrystusa?36 Wydaje się, że przypominając o tym, Tischner nie nawołuje do odrzucenia

\footnotetext{
32 J. Tischner, Spór o istnienie człowieka, op. cit., s. 176.

33 Ibidem, s. 177.

${ }^{34}$ Ibidem.

35 J. Tischner, Filozofia dramatu, op. cit., s. 104.

36 J. Tischner, Filozofia człowieka dla duszpasterzy i artystów, op. cit., s. 54.
} 
piękna, lecz raczej podporządkowania go dobru i prawdzie, mierzenia go miarą prawdy i dobra. Ostrzega więc przed pięknem pozornym, fałszywym.

W tekście Myślenie w żywiole piękna Tischner zestawia myślenie według prawdy i myślenie według piękna. Chodzi o odróżnienie myślenia uczonego i filozofa, szukających prawdy, i myślenia artysty, tworzącego dzieło sztuki. Przede wszystkim jednak chodzi o ustalenie relacji między prawdą i pięknem (sądzić chyba należy, że adresatem tych rozważań jest ten rodzaj filozofowania, który lubi zacierać granice między nauką a sztuką).

Piękno musi być jakby sprawdzone przez prawdę, bez prawdy tragedia zamienia się w farsę: „myślenie wedle prawdy spełnia funkcję krytyczną w stosunku do myślenia wedle czystego piękna" ${ }^{37}$.

Czyli trzeba najpierw wybierać według prawdy, potem według piękna. Chodzi o to, żeby piękno łączyło się dobrem, a nie usprawiedliwiało zła: „piękne jest dobro poczęte i zrodzone mimo tragedii"38 (czyli dobro, które przezwycięża rozpacz, wybrane w sposób wolny).

Wydaje się więc, że trzeba ponad piękno postawić prawdę i dobro. Ostatecznie jednak odkrywa się piękno dobra i prawdy, piękno - można powiedzieć - najwyższe, prawdziwe. Może więc raczej chodzi o oddzielenie różnych rodzajów piękna?

Trudno oprzeć się pokusie stwierdzenia, że piękno, które potrafi współdziałać z prawdą i dobrem, to jest inny rodzaj piękna niż to, które uwodzi, przyprawia o szaleństwo, a nawet stanowi dla dobra niebezpieczeństwo. To drugie to piękno estetyczne, przynależne estetycznemu stadium życia. To pierwsze to transcendentale, umieszczone przez Tischnera w przestrzeni „poza bytem i niebytem”, gdzie wydarza się dobro i gdzie „żyją transcendentalia: piękno, prawda i dobro" ${ }^{39}$. Transcendentalia są tu najwyraźniej rozumiane nie jako wymienne z bytem, tylko jako coś, co byt poprzedza, warunkuje, może nawet jest jego źródłem i usprawiedliwieniem.

Piękno, które Tischner kojarzy ze światłem i które przypisuje łasce („łaska znaczy po grecku charis - słowo to oznacza również czar, powab, wdzięk, urok, czyli to, co przysługuje pięknu"40), jest niewątpliwie właśnie tego rodzaju. Piękna jest też wolność, która jest darem łaski albo nawet łaską

${ }^{37} \mathrm{~J}$. Tischner, Myślenie w żywiole piękna, [w:] idem, Myślenie w żywiole piękna, wybór i oprac. W. Bonowicz, Kraków 2004, s. 16.

38 Ibidem, s. 18.

${ }^{39}$ J. Tischner, Spór o istnienie człowieka, op. cit., s. 200. Wydaje się, że w ostatecznym rachunku u Tischnera transcendentalia funkcjonują nie w sensie klasycznym, Tomaszowym, tylko nowożytnym, Kantowskim. Są warunkami możliwości bytu i niebytu, ludzkiego dramatu uwikłania w zło i dobro, prawdę i kłamstwo, piękno, brzydotę i piękno fałszywe.

${ }^{40}$ Ibidem, s. 129. 
samą ${ }^{41}$. Wolność i piękno stają się widzialne w tańcu i w przyrodzie. O tańcu i przyrodzie mówi Tischner, że wyzwalają piękno bezinteresowne ${ }^{42}$, wyrastające ponad konieczność. Piękno nie wypływa z przyrody, "to raczej przyroda wypływa z piękna”, przyroda "czyni wysiłki, by stać się przezroczystą dla piękna, jakby ono i tylko ono było jej usprawiedliwieniem" 43 .

Łaska, której Tischner sporo uwagi poświęca w ostatniej swojej książce Spór o istnienie świata, jest darem Dobra, wręcz cudem, który przychodzi z góry. Jest ona darem z wolności, czyli czymś nieoczekiwanym, niezasłużonym, ale nie jest ani kaprysem, ani przypadkiem. Łaska wyzwala ze zniewolenia przez zło, przeprowadza od rozpaczy do nadziei, sprawia rzeczy, które wydają się niemożliwe ${ }^{44}$. Łaska, działając „w czasie i poprzez czas" 45 , zaprowadza swój porządek, zmienia sposób przeżywania czasu, a także ustanawia relacje międzyludzkie ${ }^{46}$. Łaska wybiera, łaska powołuje, łaska usprawiedliwia - mówi Tischner ${ }^{47}$. Stworzenie, objawienie i zbawienie jest dziełem łaski, Bóg działa poprzez łaskę, a najdoskonalszą z łask jest miłość. Byt Nieskończony obdarza sobą byt skończony, pozwala mu uczestniczyć w Dobru, a racją tej łaski jest miłość48.

Znowu przydaje się metafora światła: to jest tak, pisze Tischner ${ }^{49}$, jakby ktoś mi oświecał drogę. Światło to łaska, ale poza światłem kryje się ten, który jest źródłem światła.

Dobro transcendentalne, jako pewnego rodzaju miara bytu „ponad bytem i niebytem", pojawia się u Tischnera w Myśleniu wedtug wartości. Jest ono tam "światłem”, które pozwala dostrzec, że jest coś, czego być nie powinno: zło, cierpienie, nieszczęście dotykające drugiego człowieka. Świat jawi się jako naznaczony tragicznością, zagrożony utratą dobra, możliwością zła. Budzi się bunt i myślenie, które pyta, dlaczego tak jest, a także: co można zrobić, żeby temu zaradzić. To jest początek filozofii i etyki. Doświadcze-

41 „Wolność jako sposób istnienia dobra w osobie «ratuje» skończoność w jej «starciu» z nieskończonością, nadając jej najgłębszy agatologiczny sens" - pisze trochę niejasno Tischner (ibidem, s. 188). Skończony byt ludzki odnajduje swój sens i swoją wartość, czyli usprawiedliwienie swojego bycia, tylko $\mathrm{w}$ relacji $\mathrm{z}$ nieskończonością, która jest wolnością i dobrem. Byt skończony nie miałby, można powiedzieć, racji bytu, wobec nieskończoności, która byłaby tylko czystym bytem, a nie dobrem. Ostatecznie należy więc powiedzieć, że „W chrześcijaństwie sam Bóg usprawiedliwia człowieka"; J. Tischner, Filozofia człowieka..., op. cit., s. 120.

${ }^{42} \mathrm{~J}$. Tischner, Spór o istnienie człowieka..., op. cit., s. 302-303 i 317.

43 Ibidem, s. 302-303

44 „Idea łaski wyjaśnia to, co niemożliwe do wyjaśnienia”; ibidem, s. 220.

45 Ibidem, s. 167.

46 Ibidem, s. 196-197.

47 Por. ibidem, s. 155.

48 Por. ibidem, s. 195.

49 Ibidem, s. 173 i n. 
niem źródłowym jest tu spotkanie z drugim człowiekiem, dokonujące się $\mathrm{w}$ „świetle dobra".

Poziom dramatyczny, ten, na którym rozgrywa się dramat spotkania człowieka z drugim człowiekiem, także znajduje się „poza kategoriami bytu i niebytu”50. „Logika”, która nim rządzi, ma charakter - mówi Tischner "nie ontologiczny, tylko agatologiczny i aksjologiczny" 51.

Na ślad dobra ponad bytem i niebytem, przedmiotu nieskończonego pragnienia, wchodzi Tischner, jak się wydaje, najpierw dzięki Emmanuelowi Lévinasowi, ale kiedy stara się je przybliżyć, odwołuje się do Mistrza Eckharta. W Filozofii człowieka dla duszpasterzy i artystów poświęca mu podrozdział zatytułowany Metafizyka dobra, który prawie cały jest cytatem z Eckharta: „Dobroć nie stworzona, uczyniona ani zrodzona, jest natomiast rodząca i rodzi dobrego [...]. Dobroć rodzi w dobrym siebie samą i wszystko, czym ona jest: przelewa weń byt, wiedzę, miłość i działanie [...]. Dobry i dobroć stanowią jedną i tę samą dobroć [...]. Wszystko, czym dobry jest, otrzymuje to od dobroci i w niej" 52 . Te sformułowania Tischner jeszcze nieraz przywoła w Sporze istnienie człowieka.

Choć dobro jest, jak wiele razy powtarza Tischner, ponad bytem i niebytem, nie znaczy to, że nie istnieje czy że jest jakąś ułudą53. Chodzi raczej o to, że jest ono jakoś inaczej niż my i nasz świat, i nie należy go sprowadzać do tego, co Tischner nazywa "sceną dramatu”.

Dobro, istniejąc inaczej niż byty, poprzedza je i warunkuje. Jak pisze Tischner: „w człowieku dobro i zło poprzedzają istnienie. Człowiek «bardziej jest», gdy staje się dobrym, «jest mniej» i zapada w «nicość» [...], gdy staje się złym” 54. A także: „Idea dobra wyznacza prawa bytu, szczególnie prawa bytu ludzkiego, a nie na odwrót: byt nigdy nie może być normą dla dobra, które jest ponad nim" 55 .

Dobro nie jest niczym uwarunkowane, nie ma tu przymusu ani przemocy. Nie rządzą nim związki przyczynowo-skutkowe ani logika właściwa światu bytów. Dobro ma swój własny porządek i sposób działania, który trafnie opisuje wzięta od Mistrza Eckharta metaforyka rodzenia. Można też powiedzieć, że dobro jest samorozlewne (diffusivum sui), samo się mnoży,

50 Ibidem, s. 196.

51 J. Tischner, Filozofia człowieka..., op. cit., s. 21; por. też: idem, Filozofia dramatu, op. cit., s. 53.

52 Mistrz Eckhart, Traktaty, [cyt. za:] J. Tischner, Filozofia człowieka, op. cit., s. 103.

53 To raczej zło jest złudą, czy dokładniej zjawą, która jest między bytem a niebytem, zjawą, która kusi i straszy. Por. J. Tischner, Filozofia człowieka, op. cit., s. 17; idem, Filozofia dramatu, op. cit., s. 219 i 249.

54 J. Tischner, Filozofia człowieka..., op. cit., s. 121. To uzależnienie od siebie dobra i istnienia jest analogiczne do związku piękna i substancji w ujęciu Plotyna (por. przyp. 9).

55 Ibidem, s. 111; por. też: J. Tischner, Spór o istnienie człowieka, op. cit., s. 187. 
wzrasta i obdarowuje sobą bez ograniczeń. Jest wolne i jest łaskawe. „Wolność jest sposobem istnienia dobra" - powtarza Tischner ${ }^{56}$. Jako wolność wyzwala, jako łaska obdarowuje w taki sposób, żeby wolności obdarowanego nie zniszczyć, tylko właśnie tę wolność obudzić i umożliwić jej spełnienie $^{57}$. Łaska jest nieprzewidywalna, nie można jej sprowokować, przychodzi, kiedy chce. Jest niezasłużona, darmo dana, działa według swej własnej motywacji i swego własnego porządku, porządku agatologicznego ${ }^{58}$.

Dobro domaga się jednak zaistnienia: „Absolutne Dobro domaga się zaistnienia w sposób absolutny. To, co domaga się istnienia w sposób absolutny, nie może nie istnieć. [...] Bóg - jako Dobro absolutne - istnieje" ${ }^{59}$. Tischner odwołuje się tu do Anzelmiańskiego dowodu ontologicznego, który poddaje własnej interpretacji. Odczytuje tekst św. Anzelma jako modlitwę raczej niż wywód logiczny, modlitwę i rozmyślanie nad tym, czym jest ludzki intelekt i czym jest dla człowieka Bóg. Tym, nad co nic większego nie da się pomyśleć, jest - mówi Tischner - Dobro absolutne, które nie może nie istnieć.

„Bóg nie dlatego - pisze dalej Tischner - jest absolutnym Dobrem, absolutną wolnością i świadomością, że istnieje, lecz dlatego istnieje w sposób absolutny, że jest absolutnym Dobrem, absolutną świadomością i wolnością" 60 . Dobro "ponad bytem i niebytem" nie jest więc dobrem „bez bycia”. Jest pierwotne w porządku uzasadniania: to, co jest, jest, bo jest dobre, a nie odwrotnie ${ }^{61}$. Dobro istnieć powinno, a nawet nie może nie istnieć, jeżeli jest absolutne.

Dla Tischnera zatem coś istnieje, bo jest dobre, a nie: jest dobre, bo istnieje. Dla Stróżewskiego natomiast zależność jest obustronna. Stróżewski nie obawia się, że piękno może być fałszywe. Przeciwnie, to „przez piękno sztuki widzimy świat w jego prawdziwej istocie”. „Piękno polega na zespoleniu tego, co jest, z tym, co być powinno" - mówi dalej w przemówieniu

\footnotetext{
56 „Wholność jest sposobem istnienia dobra. Dobro samo przez się jest wolne. Jest wolne w sposób absolutny. Ono jest poza strukturami bytu. Będąc samo wolne, uwalnia każdego, kto chce mieć w nim udział"; J. Tischner, Filozofia człowieka..., op. cit., s. 128.

57 „Łaska nie przekreśla wolności, lecz pozwala aby ona się spełniła” (J. Tischner, Spór o istnienie człowieka, op. cit., s. 131); „Bóg jest najwyższym «budzicielem» wolności. Bóg jest najwyższym dobrem. Gdzie jest najwyższe dobro, jest też największa wolność" (J. Tischner, Filozofia człowieka..., op. cit., s. 129).

58 Por. J. Tischner, Spór o istnienie człowieka, op. cit., s. 130.

${ }^{59}$ Ibidem, s. 270.

${ }^{60}$ Ibidem, s. 272.

61 „Logika dialogiczności jest jednak «wyższa» niż «logika bycia». To nie bycie usprawiedliwia dobro, lecz dobro usprawiedliwia bycie"; ibidem, s. 187.
} 
z okazji przyznania doktoratu honoris causa Uniwersytetu Jagiellońskiego, które można uznać za jego credo $^{62}$.

Wśród stałych idei piękna Stróżewski wyróżnia moment najwyższości i moment konieczności63. Czasem dodaje też moment transcendencji64. Piękno jest więc przede wszystkim najwyższą doskonałością pośród wszystkich wartości estetycznych: „tylko jemu przysługuje moment najwyższości”65.

Piękno ukazuje się jako konieczne ${ }^{66}$ : jako coś, co wzywa i zobowiązuje, niczym rodzaj aksjologicznego imperatywu kategorycznego, czy też jako coś zrealizowanego i wzbudzającego zachwyt i olśnienie. Jest to konieczność szczególna ${ }^{67}$, nazwana aksjologiczną; w odróżnieniu od deterministycznej68 jest ona indywidualna, niepowtarzalna, dotyczy realizacji konkretnego dzieła przez konkretnego artystę, dzieła, które ma powstać dokładnie według najwyższej, właśnie dla niego przeznaczonej miary.

To, co najwyższe, budzi zachwyt, olśniewa i porywa. Porusza i pociąga, wznosi do góry, budzi pragnienie uczestnictwa w czymś wielkim ${ }^{69}$. Piękno może więc wprowadzać w sferę wartości wyższych niż estetyczne, nazwanych przez Stróżewskiego nadestetycznymi (takich jak np. prawda, wartości moralne, sacrum; pokrewne im są Ingardenowskie jakości metafizyczne).

Moment transcendencji można więc rozumieć jako wychodzenie, wychylanie się ku pięknu, ale także jako wznoszenie się do wartości nadestetycznych. Piękno przekracza wszystkie wartości, „z sobą samym włącznie” mówi Stróżewski w swoim „credo"70. Z tym że odsłanianie wartości nadestetycznych dokonuje się właśnie dzięki pięknu, za jego sprawą: piękno „zjednoczone z ponadestetyczną wartością staje się jej koniecznym dopeł-

62 W. Stróżewski, Przemówienie wygłoszone w czasie uroczystości nadania doktoratu honoris causa Uniwersytetu Jagiellońskiego w dniu 27 czerwca 2003 roku, „Ruch Filozoficzny” 2004, tom LXI, nr 1, s. 6.

63 W. Stróżewski, Problematyka piękna, [w:] idem, Logos, wartość, miłość, Kraków 2013, s. 430.

${ }^{64}$ W. Stróżewski, Wokót piękna, [w:] idem, Wokót piękna, Kraków 2002, s. 167-169 i 190.

65 W. Stróżewski, Problematyka piękna, op. cit., s. 431.

66 „To, co jest, jest takie, jakie powinno być: powinność i jej doskonałe spełnienie [...] nakładają się na siebie"; ibidem, s. 430.

67 Zwykle ilustruje ją odwołanie do Beethovenowskiej notatki na marginesie partytury: Muss es sein? Es muss sein. Por. np.: W. Stróżewski, Wolność i wartość, [w:] idem, O wielkości, Kraków 2002, s. 262.

68 Ibidem, s. 265.

69 Piękno może też pociągać do złego, ale ulega wtedy profanacji. „Gdy działa samo w sobie, zawsze pociąga ku górze, niekiedy nawet ku wartościom, które przekraczają je samo. Użyte wyłącznie jako narzędzie przestaje być de facto sobą. Ale tak samo dzieje się przecież z dobrem" (W. Stróżewski, Problematyka piękna, op. cit., s. 428-429). Można to rozumieć jako polemikę z poglądem, że piękno miałoby jakoś bardziej niż inne wartości sprowadzać na manowce.

70 Por. przypis 62. 
nieniem, jej blaskiem"71. Wartości promieniują - na tym polega ich działanie, a promieniowanie, świetlistość, to właśnie piękno. Piękno jest wartościowością wartości - tak Stróżewski odpowiada na pytanie o istotę wartości w ogóle, o jej arche, o zasadę wartościowości ${ }^{72}$. Piękno jest więc w każdej wartości jej blaskiem. Ono sprawia, że wartość przyciąga, zachwyca, zobowiązuje.

Piękno estetyczne przekracza tu siebie i staje się czymś więcej, nadpięknem; można też powiedzieć - pięknem metafizycznym czy też transcendentalnym. Jest ono - mówi Stróżewski - „najbliższe [...] sięgnięcia Absolutu”73. Pisze też o doświadczeniu, w którym „stając w zachwycie w obliczu piękna [...], afirmujemy spontanicznie oczywistość jego istnienia. Pięknie jest, że jest. I że jest właśnie pięknem" 74 .

Zachwyt i pragnienie „uczestnictwa w pięknie, stopienia się z nim [...], współbycia” przeprowadza „od doświadczenia piękna do doświadczenia istnienia"75. Istnienie piękna jest istnieniem prawdziwym ${ }^{76}$.

Ważne okazuje się więc, pozornie tylko porządkujące, oddzielenie piękna w sensie estetycznym i piękna w sensie metafizycznym czy transcendentalnym. Są to dwa poziomy: wartość i transcendentale 77 . Dopiero na poziomie transcendentaliów można mówić o jedności istnienia i piękna i o ich pełnej doskonałości. Pełnia jest tu celem, przedmiotem pragnienia i dążenia, horyzontem i miarą. „Metafizyczne piękno, jako transcendentale utożsamione $\mathrm{z}$ istnieniem, jest także $\mathrm{w}$ swej istocie Logosem, najgłębszym sensem przenikającym to, co jest"78 - oto ostateczny sens najwyższości piękna. Dopiero tego rodzaju piękno, metafizyczne, może stać się blaskiem każdej wartości i nie tylko nie może być podejrzewane o fałsz, ale też staje się gwarantem prawdy.

Piękno transcendentalne związane jest z konkretnymi koncepcjami metafizycznymi: św. Tomasza z Akwinu, Dionizego Areopagity (którego rola staje się tu coraz znaczniejsza). Stróżewski odwołuje się też do doświadczenia, czy raczej eksperymentu myślowego, odwrotnego do doświadczenia trwogi opisywanego przez Martina Heideggera: oto z nicości przechodzimy do bytu, do istnienia. „Czy zaistnienie objawiło by się nam jako stan całko-

\footnotetext{
${ }^{71}$ W. Stróżewski, Wartości estetyczne i nadestetyczne, [w:] idem, Wokót piękna, op. cit., s. 192.

72 Por. W. Stróżewski, W poszukiwaniu istoty wartości, [w:] idem, Logos, wartość, mitość, s. 70.

73 Por. przypis 62.

${ }^{74}$ W. Stróżewski, Trzy wymiary dzieła sztuki, [w:] idem, Wokót piękna, op. cit., s. 31.

${ }^{75}$ W. Stróżewski, Istnienie i piękno, [w:] idem, O wielkości, op. cit., s. 275.

76 Ibidem, s. 276.

77 Stróżewski pisze, że wartość jest uszczegółowieniem transcendentaliów; por. W. Stróżewski, $W$ poszukiwaniu istoty wartości, op. cit., s. 70.

${ }^{78}$ W. Stróżewski, Piękno transcendentalne, [w:] idem, Logos, wartość, mitość, op. cit., s. 83.
} 
wicie neutralny, niebudzący żadnych emocji? Czy możemy sobie wyobrazić, że nie towarzyszyło mu przynajmniej zdziwienie, a w dalszym ciągu olśnienie, uderzenie światła, zachwyt?"79 O czymś podobnym mówi też Platon, kiedy opisuje wyjście z jaskini na światło, a także Czesław Miłosz w swoim wierszu Esse. Jak pisze Stróżewski: „Światłem jest to, co jest. Ono jest pięknem wywołującym radość. Radość z tego, że jest. Bo cóż warte by było nieistniejące piękno?" 80

W zachwycie i olśnieniu dane jest „widzenie istnienia w pięknie”, tu „nie ma mowy o braku", bo jest pełnia i doskonałość, jednostkowe byty uczestniczą w pełni istnienia, rzeczy piękne mają udział w pięknie ${ }^{81}$.

Można więc mówić, że piękno nie tylko intensyfikuje, wyostrza i uwydatnia istotne cechy przedmiotu, ale też czyni go prawdziwszym; ogólnie rzecz ujmując: „wartość sprawia, że istota rzeczy ujawnia się w jej prawdzie" 82, czy wręcz: „Poezja ma moc objawiania Transcendencji poprzez słowo" 83 .

Piękno odsłania prawdę, staje się znakiem prawdy, jej świadectwem. O to chodzi Stróżewskiemu, kiedy wśród trzech dróg sprawdzania przeświadczeń wymienia też drogę poezji „,z regulatywną ideą prawdy poprzez piękno"84. Poezja, „wywiedziona z głębi doświadczenia poety”85, jest wyznaniem i objawieniem, jej prawda uderza, inspiruje i zmusza do akceptacji. Objawia rzeczywistość, do której inaczej nie mamy dostępu, rzeczywistość transcendentną, spokrewnioną $\mathrm{z}$ dziedziną czystych istot. Poezją rządzi „Logos, ten sam, który nadaje sens całej rzeczywistości”"86.

Piękno i prawda zjednoczone są w rzeczywistości najwyższej, nazwanej tu rzeczywistością transcendentną, i dzięki tej jedności mogą na siebie nawzajem wskazywać. Dlatego możliwe to jest tylko w przypadku poezji wielkiej: „Ta wielkość wypływa z jej prawdziwości i związanego z nią piękna" 87 .

\footnotetext{
${ }^{79}$ Ibidem, s. 81

${ }^{80}$ Ibidem.

${ }^{81}$ Czym jest jednak brzydota i zło - przecież one też istnieją? - pyta Stróżewski, i odpowiada: istnieją, ale nie na tym samym poziomie. „Upierałbym się przy zdaniu, że brzydota, zło nie sięgają metafizycznego poziomu istnienia” - pisze. „Więcej, że na tym poziomie mogą być jakoś zrównoważone, a nawet zniwelowane" (ibidem, s. 83). Podobne to jest do Tischnerowskiego ujęcia zła jako złudy, czyli czegoś, co jest więcej niż tylko brakiem, ale mniej niż pełnym, samodzielnym istnieniem.

82 W. Stróżewski, W poszukiwaniu istoty wartości, op. cit., s. 77.

${ }^{83}$ W. Stróżewski, O metafizyczności w sztuce, [w:] idem, Wokót piękna, op. cit., s. 131.

84 W. Stróżewski, O przeświadczeniach, [w:] idem, Logos, wartość, mitość, op. cit., s. 110.

85 Ibidem, s. 100.

86 Ibidem.

87 Ibidem.
} 
To nie człowiek-artysta sprawia, że pojawia się piękno. „Artysta przygotowuje tylko warunki dla piękna, ono samo przychodzi skądinąd" - pisze Stróżewski. Piękno jest „czymś niematerialnym, duchowym, dołączającym się niejako do materialnych uwarunkowań, które je jedynie przygotowują" 88 . Stróżewski powołuje się tu na Augusta Zamoyskiego, Arnolda Schönberga, Cypriana Kamila Norwida, Reinera Rilkego i jego metafore przygotowywania ołtarza, który czekać musi na ogień z nieba ${ }^{89}$. „To nie sztuka tworzy piękno, lecz piękno tworzy sztukę" - stwierdza w swoim „credo"90. Stróżewski podąża tu także śladami starszej tradycji: Platona, Plotyna czy św. Augustyna, którego zdanie, że piękne dzieła mają źródło w wyższej piękności, przytacza ${ }^{91}$.

Zatem piękno (podobne $\mathrm{w}$ tym do dobra i do istnienia) jest czymś, co samo przychodzi, samo się objawia. Nie jesteśmy w stanie nad tym zapanować, nie można tym dysponować ani manipulować ${ }^{22}$. Piękno przychodzi z góry i pociąga nas do góry: „Zachodzi tu niezwykła dialektyka: od tego świata idei pochodzi dobro i piękno, ale do tego świata wraca, gdy tu i teraz zostało optymalnie zrealizowane" ${ }^{\prime \prime}$.

Jest więc w świecie wartości dynamika: wartość - czyli także piękno - to zdolność do „«wyjścia z siebie» w celu wzbogacenia czegoś innego, oddania mu czegoś z siebie”; "wartość nie jest cechą, [...] lecz sposobem istnienia zależnym także od tego, ku czemu jest [...] «wychylony»"94. Jest tu życie i ruch: wychylania się i wzrastania, tworzenia i dopełniania, wreszcie osiągania uczestnictwa w dobru i pięknie. A także ruch dawania siebie, ofiarowywania; sama wartość tak czyni: bonum est diffisivum sui (także Tischner lubił powtarzać to zdanie).

Jest to dynamika miłości - tej, która jest porwana przez zachwyt, i tej, która siebie rozdaje. Miłość nie tylko jest odpowiedzią na wartość, ale czymś, co wartość konstytuuje. Miłość prowokuje miłość - mówi Stróżew-

88 W. Stróżewski, Problematyka piękna, op. cit., s.421

89 W. Stróżewski, Istnienie i piękno, op. cit., s. 279.

90 Por. przyp. 62; por. też: „Wartości nie tworzy się wprost, lecz jedynie przez przygotowywanie warunków ich realizacji” (W. Stróżewski, O swoistości sposobu istnienia człowieka, [w:] idem, O wielkości, op. cit., s. 78); oraz: „Czystość przygotowuje miejsce dla daru. Nie można stworzyć arcydzieła, polegając wyłącznie na swojej sprawności. Artysta przygotowuje jedynie warunki na to, by w jego dziele objawiła się wartość" (W. Stróżewski, O wielkości, op. cit., s. 310).

${ }^{91}$ Por. W. Stróżewski, Problematyka piękna, op. cit., s. 421-422.

92 Opis doświadczenia piękna i dobra jako darów mógłby posłużyć jako argument przeciwko zarzutom, że u źródła wartości leży wola mocy

93 W. Stróżewski, Istnienie i piękno, op. cit., s. 280.

${ }^{44}$ W. Stróżewski, W poszukiwaniu istoty wartości, op. cit., s. 69-71. 
ski, i za Norwidem dopowiada wprost: piękno kształtem jest miłości. Miłość jest siłą twórczą, która sama sobie nadaje kształt, miłość jest sprawcą, przyczyną piękna. Inaczej niż u Platona, gdzie „miłość była reakcją na piękno, piękno ją wyzwalało i prowadziło na coraz wyższe poziomu rzeczywistości”, „u Norwida pierwsza jest miłość” i „od jej dostrzeżenia [...] zależy doświadczenie piękna”95. Pisze Stróżewski: „Bóg stworzył świat z miłości i to właśnie jest przyczyną, że wszystko, co jest, jest piękne. Norwid wpisuje się tu w głęboką chrześcijańską prawdę o pankalii, wyrażoną przez Ojców Kościoła"96, w tym przez Dionizego Areopagitę: „to, co piękne, uczestniczy w piękności, nad którą wznosi się nie dająca się wyrazić przyczyna wszystkiego" 97 .

Przy wszystkich łatwo dostrzegalnych różnicach u obu myślicieli dominuje to samo zasadnicze przekonanie: to, co najważniejsze, przychodzi z góry - jest darem, niezasłużonym i nieprzewidywalnym, darem absolutu, który jest dobrem i Miłością, a to, co od niego przychodzi, określa się jako blask lub światło, łaska, wolność lub piękno. Jest to schemat neoplatoński, przekazany chrześcijaństwu przez św. Augustyna i Dionizego Areopagitę.

Według Stróżewskiego, tak samo jak według Tischnera, świat jest otwarty, a człowiek jest jego współtwórcą, wezwanym do działania i tworzenia, tworzenia zarówno dzieł sztuki, jak i tego, co międzyludzkie. Choć w ostatecznym rachunku, w tym, co najważniejsze, człowiek zdany jest w swojej twórczości na to, co przychodzi z góry jako dar i łaska.

Stróżewski i Tischner podejmują tę samą neoplatońską tradycje, podchodzą tylko do niej od dwóch różnych stron. Są to dwie strony jednego dążenia i żadna z nich nie może zlekceważyć tej drugiej. Stróżewski podkreśla raczej jedność, Tischner rozbicie i dramatyczność. Stróżewski na swej drodze natrafia na wielość, a nawet przeciwieństwa i sprzeczności, na nicość (i stąd potrzeba odwołania się do dialektyki). Tischner szuka jedności i pełni, które nazywa zbawieniem, szuka sposobu przekroczenia przepaści między zagubionym człowiekiem i absolutem.

Ostatecznie chodzi o odnalezienie drogi do absolutu i do swojego, człowieczego udziału w nim. „Byłoby naszą dramatyczną klęską, gdyby te drogi i ich idee okazały się także tylko pustymi przeświadczeniami" ${ }^{98}$.

95 W. Stróżewski, Glossa do: Cyprian Norwid, „Prometihdion” (w. 108-121), [w:] idem: Logos, wartość, miłość, op. cit., s. 235-236.

96 Ibidem, s. 236.

97 Ibidem, s. 244.

98 W. Stróżewski, O przeświadczeniach, op. cit., s.111. 


\section{Beauty as the Raiment of the Good. From Plotinus to Stróżewski and Tischner}

\section{Summary}

The relationship between goodness and beauty has been considered by philosophers since ancient times. Plato identified them with one another. According to Plotinus and other Neoplatonists beauty has its origin in the good, reveals it, and directs us to it. The Middle Ages continued this tradition, reflected in the theory of the transcendentals and in the understanding of beauty as harmony and radiance. In contemporary Polish philosophy, Platonic and especially Neoplatonic themes can be found in the thought of Władysław Stróżewski and Józef Tischner. They represent a common feature of the two conceptions, which otherwise differ in many respects. For Tischner beauty turns out to be not only an element, in which one can lose oneself, but also light and grace, a gift of the highest good. According to Stróżewski beauty, understood as radiance and perfection, comes as a gift from above, and inclines one to rise to what is highest (trans. Jarosław Olesiak). 